\title{
Transition to higher education; prospective and retrospective student experiences
}

\author{
Ian Piper $^{\mathrm{a}}$, Alison Kelly ${ }^{\mathrm{a}} \&$ Hilda Mulrooney ${ }^{\mathrm{a}^{*}}$ \\ aSchool of Life Sciences, Pharmacy \& Chemistry, SEC Faculty, \\ Kingston University, Penrhyn Road, Kingston upon Thames, London, UK. \\ *Corresponding Author: Hilda.mulrooney@kingston.ac.uk \\ Orcid ID: HM: 0000-0001-7257-5119
}

Keywords: Transition; Induction; Belonging; Retention; Support

\begin{abstract}
Pre-university (foundation or Level 3) study attracts significant student numbers annually, but approximately $10 \%$ of successful Level 3 students do not progress into their university degrees. This project aimed to identify the experiences of current and previous Level 3 students, using questionnaires and focus groups to explore differences by gender, ethnicity and intention to study. One hundred and two current and 56 previous level 3 students participated. Those who felt part of the university were significantly more likely to agree that the foundation course met their expectations. Personal support from academic staff, was highly ranked by students in all year groups, peaking in the final year. Despite considerable student diversity, the foundation year met expectations. However this was significantly lower for Black students compared with other ethnicities, which needs further exploration. Fostering 'belonging' to university is important for foundation year students to improve retention rates into their degree courses.
\end{abstract}

\section{Introduction}

The Extended degree, in which students take an additional foundation year (Level 3) at Kingston College, is an important part of the recruitment effort at Kingston University. It attracts large numbers of mature and Black and minority ethnic (BME) applicants annually. However approximately $10 \%$ of eligible Level 3 students who successfully complete the foundation year do not progress into Level 4 at the university. It is recognised that starting at university is a time of transition (Jindal-Snape, 2010), and how students adjust to this impacts upon the rest of their university experience (Strayhorn, 2012; Ramsay et al, 2005) as well as future achievements (Hultberg et al, 2008). Coping with change can be difficult (Jackson, 2010), especially if it is not what was expected or anticipated (Denovan \& Macaskill, 2013; Maunder et al, 2013). Social, academic, financial and environmental challenges have been described (Cheng et al, 2015a), some or all of which may be experienced by individuals. Students need to be prepared to negotiate their place and find their voices within this new learning community (Price et al, 2011). Extended degrees tend to attract students from non-traditional backgrounds (Gill, 2019), as part of a national widening participation background. Adjusting to higher education may be more difficult for nontraditional students (Reay, 2008; Crossan et al, 2003; O'Donnell \& Tobbell, 2007; Reay et al, 2010) including students who are first generation to higher education (Waite, 2013; Wainwright \& Marandet, 2010; O'Shea, 2015, 2016), mature students (Reay, 2008) and those who commute (Southall et al, 2016). It follows that supporting them through this transition is important. Now is a time of acute pressures within the higher education sector, 
and successful recruitment and retention of students is a key issue for institutions. The foundation year acts as a bridge between school and university, and may simultaneously represent a safe environment for students (with the structured support of college (Frame et al, 2006)), and a disappointment (that it is not university proper). This may be more acute if the student did not make a decision themselves to take the extended degree; rather their examination results, previous subject choices or experience to date required them to take the foundation year beforehand. The foundation year experience represents a useful lens through which to explore the nature of transition from the student perspective. Transition has been described as 'the capability to navigate change' (Gale \& Parker, 2014), conceptualised within higher education as induction, development and becoming (Gale \& Parker, 2014; O'Donnell et al, 2016). Different models of transition are described in the literature (Cheng et al, 2015a), but they all involve different phases students must negotiate in order to successfully adapt to higher education. Transition is now recognised as not solely occurring in the first year of university life but throughout students' time of study (Tobolowsky et al, 2008; Maunder et al, 2013). If it is accepted that transition is an ongoing process then it is likely that adjustment of both levels and types of support available to students will be required, depending on their needs at that time (Jindal-Snape, 2010; Cheng et al, 2015a). Ensuring that students are aware of and can access suitable support is also required (Tett et al, 2017). In this project we aimed to explore the experience, expectations, hopes and fears of foundation students from two perspectives; those of current Level 3 students, in addition to a retrospective view from previous foundation students now in Levels 4, 5 and 6 at Kingston university. Although we explored a particular group of students, many universities now accredit courses and degrees housed elsewhere. Issues identified in this project therefore have wider applicability.

\section{Methods}

This project was a staff: student collaborative project for which ethics approval was granted by the Kingston University Centre for Higher Education Research and Practice Research Ethics Committee.

\section{Data sources}

Quantitative data was collected by questionnaire. Two were developed, one each for current and previous Level 3 students.

\section{Both questionnaires}

Questions common to both questionnaires included the student journey into Level 3, whether or not they had intended to do a foundation degree and whether it was their idea or that of an academic. Demographic data collected included age, gender, ethnicity, marital status, educational background (e.g. A levels, Access course, BTEC vocational qualifications), and whether the student was the first member of their family to attend university.

\section{Questionnaire for current Level 3 students}

Five point Likert rating scales (from 'strongly agree' to strongly disagree') were used to ascertain level of agreement with the accuracy of course description, whether the induction helped students to integrate into their course, whether or not the course met their expectations, perceived relevance of the foundation course content to the degree programme and perceived adequacy of subject-specific support. Whether students were glad to be taking the foundation year, whether they felt part of the college and/or the university, current confidence levels and anticipated confidence levels about entering Level 4 were also collected using five point Likert rating scales (from 'completely confident' to 'completely unconfident'). Open text boxes within the questionnaires were used to collect additional comments relating to the induction, feelings of belonging to the college and/or the university, and confidence about Level 4 study. A final text box allowed respondents to add any further comments they had.

\section{Questionnaires for previous Level 3 students (now at Levels 4, 5 and 6)}

Thinking back to their experience of transition from Level 3, students were asked to rate different types of support in order of importance (from 1 to 7 , with 1 being most 
and 7 being least important). Types of support specified included library, I.T., support from personal tutors, office hours or individual academics, university academic support (e.g. study support) and other university support (e.g. counselling).

Five point Likert rating scales were used to ascertain level of agreement with a series of statements relating to workload, support with transition, whether the foundation course was useful preparation for Level 4, whether the content of Level 3 had helped with their degree studies, whether they would recommend foundation year to other students, whether they enjoyed the foundation year and whether they were glad they took this route into university. In addition they were asked to rate the extent to which they agreed that they felt part of Kingston University, and part of Kingston College. Retrospective confidence levels about moving from Level 3 to Level 4 were gathered using a five point Likert rating scale (from 'completely unconfident' to 'completely confident'). Qualitative data was collected using open boxes for students to record additional support they had found useful, what would have helped them to feel more confident and text boxes to further explain their answers to Likert rating scale questions.

\section{Questionnaire distribution}

Questionnaires for current Level 3 students were distributed face-to-face by prior arrangement with the college, at specific sessions with large numbers of registered students. A participant information sheet and short verbal introduction was given before questionnaires were distributed and completed immediately. All sessions included at least one staff partner and most included a student partner. Completion of the questionnaire took approximately 10 minutes.

Questionnaires for Levels 4, 5 and 6 students were distributed via university email addresses with personalised invitations to participate which included a link to the survey. This approach was used in order to avoid foundation degree students feeling singled out within large modules, affording them privacy in deciding whether or not to participate.
However as a result participation rates among eligible students were disappointingly low.

\section{Focus groups}

Students at all levels who indicated willingness to participate in focus groups were contacted via university or college emails they supplied. A short focus group guide was developed and all sessions were facilitated by two student partners; discussions were audio recorded.

\section{Data analysis}

Level 3 questionnaire data were coded and entered into an Excel spreadsheet. As no individual identifiable data was collected, data within the spreadsheet was anonymous. Email addresses of those who wished to participate in focus groups were used only to organise focus group sessions and removed thereafter. Anonymous questionnaire data from the online surveys for Level 4, 5 and 6 students was downloaded verbatim into separate spreadsheets by level.

Descriptive statistics of the sample were taken by year of study. Data were analysed by age, gender and ethnicity to determine whether these factors influenced participant responses. As data were non-parametric, chisquare tests were used to identify differences in responses between groups. A significance level of $\mathrm{p}<0.05$ was used in all tests. For support sources rated $1-7$ by Level 4,5 and 6 students, the mean ratings were calculated. The lower the score, the more highly rated a support source was (since $1=$ most and 7=least important).

\section{Results \\ Participants}

Study participants were limited to current Level 3 students ( $n=102$ respondents) at Kingston College, as well as previous Level 3 students now in Level 4 ( $n=10$ respondents), Level 5 ( $n=18$ respondents) and Level 6 $(\mathrm{n}=28$ respondents) at Kingston University. These response rates represented $37.4 \%$, $4.7 \%, 7.8 \%$ and $19.6 \%$ (Levels $3-6$ ) of eligible students respectively. Two focus groups were held. No secondary data were used. 


\begin{tabular}{|c|c|c|c|c|c|}
\hline & Level 3 & Level 4 & Level 5 & Level 6 & $\begin{array}{l}\text { Faculty data } \\
\text { for 2019-20 }\end{array}$ \\
\hline \multicolumn{6}{|c|}{ Gender } \\
\hline Males & $46(45)$ & $3(30)$ & $6(33)$ & $20(71)$ & $61.7 \%$ \\
\hline Females & $51(50)$ & $5(50)$ & $12(67)$ & $7(25)$ & $38.0 \%$ \\
\hline PNS* & $4(4)$ & $2(20)$ & $0(0)$ & $1(4)$ & $0.0 \%$ \\
\hline Other & $1(1)$ & $0(0)$ & $0(0)$ & $0(0)$ & $0.3 \%$ \\
\hline Total & $102(100)$ & $10(100)$ & $18(100)$ & $28(100)$ & $100 \%$ \\
\hline \multicolumn{6}{|c|}{ Age } \\
\hline$<21$ years & $67(66)$ & $7(70)$ & $4(22)$ & $0(0)$ & $49.7 \%$ \\
\hline$\geq 21$ years & $20(20)$ & $2(20)$ & $13(72)$ & $27(96)$ & $50.3 \%$ \\
\hline PNS* & $15(14)$ & $1(10)$ & $1(6)$ & $1(4)$ & $0.0 \%$ \\
\hline Total & $102(100)$ & $10(100)$ & $18(100)$ & $28(100)$ & $100 \%$ \\
\hline \multicolumn{6}{|c|}{ Ethnicity } \\
\hline White & $27(26)$ & $1(10)$ & $9(50)$ & $15(54)$ & $27.6 \%$ \\
\hline Black & $19(19)$ & $2(20)$ & $2(11)$ & $5(18)$ & $16.6 \%$ \\
\hline Asian & $35(34)$ & $4(40)$ & $3(17)$ & $4(14)$ & $40.8 \%$ \\
\hline Mixed & $8(8)$ & $0(0)$ & $3(17)$ & $1(4)$ & $13.7 \%$ \\
\hline PNS* & $13(13)$ & $3(30)$ & $1(5)$ & $3(11)$ & $1.3 \%$ \\
\hline Total & $102(100)$ & $10(100)$ & $18(100)$ & $28(100)$ & $100 \%$ \\
\hline
\end{tabular}

Table 1: Demographics of study participants expressed as numbers (\%). *PNS = prefer not to say.

Demographic data is shown in Table 1. The study population was ethnically diverse; $61 \%$, $60 \%, 45 \%$ and $36 \%$ respectively of Level 3, 4 , 5 and 6 respondents being from Black and minority ethnic groups (BME). At Levels 3 and 4 approximately two thirds of respondents were aged <21 years; the majority of respondents at Levels 5 and 6 were $\geq 21$ years. There were more females than males in all groups with the exception of Level 6 .

Compared with the demographic breakdown for the Faculty as a whole, the study included a slightly higher representation of females (47\% vs. $38 \%$ ), White (33\% vs. $27.6 \%$ ), and Black students (18\% vs. $16.6 \%)$. By contrast, there was a lower representation of Asian $(29 \%$ vs. $40.8 \%)$ and mixed race students ( $7.6 \%$ vs. $13.7 \%$ ). The proportion of younger \& older students who participated was similar to that seen in the Faculty.

Male and female students at Level 3 had entered foundation through similar routes; the majority via A Levels (69\% females and $46 \%$ males) or BTEC programmes (18\% females and $33 \%$ males respectively).

\section{Level 3 responses}

Age

Age-related differences in perceived accuracy of induction were seen; students aged $\geq 21$ years were significantly more likely to agree or strongly agree that the course was accurately described to them than those aged $<21$ years $\left(\chi^{2}\right.$ (df 5) 15.2, $\left.p=0.009\right)$. Younger students were significantly more likely to feel glad that they had taken the foundation year compared with older students $\left(\chi^{2}\right.$ (df 5) 11.8, $p=0.04$ ). Those $<21$ years were significantly more likely to have taken $A$ levels and access courses than those aged $\geq 21$ years $\left(\chi^{2}\right.$ (df 6) 14.5, $p=0.006$ ). No other differences by age were seen.

\section{Gender}

Statistically more females than males were aged $<21$ years $\left(\chi^{2}\right.$ (df 4) 18.6, $p=0.001$ ), single $\left(\chi^{2}\right.$ (df 6) 29.2, $\left.p=0.0001\right)$ or Black $\left(\chi^{2}\right.$ (df 8) 22.2, $p=0.005$ ).

Significantly more females than males were first in their families to attend university (39\% versus $24 \%$ respectively; $\chi^{2}$ (df 6 ) 29.7, 
$p=0.000)$. More females than males expressed confidence now about going into Level 4 ( $\chi^{2}$ (df 10) 26.7, $p=0.003$ ).

\section{Ethnicity}

Significantly more White and Asian students agreed that the foundation year was meeting their expectations, compared with other ethnicities $\left(\chi^{2}\right.$ (df 20) 44.7, $p=0.001$ ). Although there were no significant differences in current confidence levels by ethnicity, significantly more Asian students expected they would feel confident or highly confident about entering Level 4 after completing the foundation year, compared with other ethnic groups ( $\chi^{2}$ (df 20) 41.2, $p=0.004$ ).

There were no differences by ethnicity with levels of agreement that the course had been accurately described on application or in clearing. However, a greater proportion of Black students $(37 \%)$ disagreed or strongly disagreed that the course description was accurate compared with white $(15 \%)$, mixed $(12.5 \%)$ and Asian students (29\%). Mixed and Black students had lowest levels of agreement that the induction helped them to feel comfortable and integrated into their course; $12.5 \%$ and $16 \%$ respectively disagreed or strongly disagreed. Levels of satisfaction with induction in Black students were significantly lower than those in White and Asian students ( $\chi^{2}$ (df 20) 34.9, $p=0.02$ ). The specific reasons for this are unclear. Of those black students who were dissatisfied, the majority were female $(73 \%)$, single $(82 \%)$ and had entered university via $A$ levels (64\%). Only $27 \%$ of this group were first in their family to university. We did not ask about time or length of commute or caring responsibilities, and it is possible that the lower levels of satisfaction expressed were driven by a combination of risks in this group rather than a single factor. Although this was a small number of students, differential rates of satisfaction with induction by ethnicity would be worth exploring further.

A substantial proportion of students within each ethnic group were first in their families to attend university. This was greater for mixed race and Asian students (50\% and $43 \%$ first to university respectively, $p=0.05$ ).

\section{Intention to take the foundation year}

Overall, $40 \%$ of all foundation students had intentionally applied for the extended degree. Whether or not students intended to take the foundation route did not impact upon their confidence about entering Level 4 ( $\chi^{2}$ (df 5) 2.16, $p=0.71$ ) or whether the course met their expectations $\left(\chi^{2}\right.$ (df 5) 6.10, $\left.p=0.19\right)$. Intending to take the foundation year did not impact on whether students felt part of the university $\left(\chi^{2}\right.$ (df 5) 3.77, $\left.p=0.44\right)$ or the college $\left(\chi^{2}\right.$ (df 4) 1.95, $p=0.75$ )

\section{'Belongingness'}

Data were examined to see whether feeling part of the university and/or the college made a difference to experiences and perceptions of Level 3 students. The most important findings were that students were more likely to agree or strongly agree that the foundation course met their expectations if they also agreed or strongly agreed that they felt part of the university $\left(\chi^{2}\right.$ (df 9) 26.6, $p=0.002$ ).

By contrast, there was no relationship between feeling part of the college and whether the foundation course met expectations ( $\chi^{2}$ (df 6) 12.00, $p=0.06$ ). In terms of confidence about Level 4 , the only relationship which reached statistical significance was that between feeling part of the university, and anticipated levels of confidence about entering Level 4 later $\left(\chi^{2}\right.$ (df 9) 26.1, $p=0.002$ ). Although overall expected confidence levels were high whether or not students felt part of the university, those who did not were more likely to be less confident or ambivalent about their confidence levels.

\section{Level 4, 5 and 6 students}

Preferred sources of support differed depending on the level of study (Table 2). For Level 4 students both academic skills acquisition and personal support were highlighted, with most importance given to personal tutors, academic support e.g. academic skills development and academic office hours. Similarly for Level 5 students personal support was important (personal tutors and individual academics rating highest), as well as support from the library. In Level 6, personal support was most highly rated; the most important sources of support 


\begin{tabular}{|l|c|c|c|}
\hline \multicolumn{1}{|c|}{ Support } & Level 4 & Level 5 & Level 6 \\
\hline Library & $4.43 \pm 2.30$ & $3.33 \pm 1.40$ & $3.47 \pm 1.63$ \\
\hline I.T & $4.44 \pm 2.07$ & $5.13 \pm 1.82$ & $4.00 \pm 2.04$ \\
\hline Personal tutor & $3.25 \pm 1.39$ & $3.13 \pm 1.63$ & $3.31 \pm 2.15$ \\
\hline Office hours & $3.75 \pm 2.12$ & $3.56 \pm 1.98$ & $4.00 \pm 1.79$ \\
\hline Individual academics & $4.44 \pm 2.01$ & $3.33 \pm 1.91$ & $2.42 \pm 1.70$ \\
\hline Academic study support & $3.33 \pm 1.75$ & $4.63 \pm 2.06$ & $4.73 \pm 1.60$ \\
\hline Other university support & $5.63 \pm 1.85$ & $4.89 \pm 2.11$ & $4.93 \pm 2.02$ \\
\hline e.g. counselling & & & \\
\hline
\end{tabular}

Table 2: Importance of different sources of support rated by previous foundation students currently studying in Levels 4,5 and 6 (expressed as means $\pm S D$ ); each source rated from 1-7 where 1 is most and 7 is least important).

identified were individual academics, personal tutors and finally support from the library.

This suggests that support needs change as students' progress through their learning journey, but individual personal support remains a constant source of help and appears to assume greater importance as study progresses. Scores for individual academics indicated that their support increased in importance from Level 4 to Level 5 , peaking in Level 6 , where relationships are likely to be $1: 1$ due to project supervision. Between Levels 4 and 6 however the score for formal academic support (e.g. study skills) declined, perhaps suggesting that students had already gained those skills and required different support.

No differences in confidence about entering Level 4 from Level 3 were seen between males and females at any level of study $(p=0.24)$. No significant differences were seen in response to perceptions of receiving appropriate support transitioning from Level 3 to Level $4(p=0.12)$. There were no significant differences between Level 4, 5 or 6 students in whether or not they felt part of the university $(p=0.72)$, or the college $(p=0.13)$. There were no significant differences between those students who had intended to take a foundation year compared with those who did not, for appropriateness of the foundation course content $(p=0.08)$, perception of transition support received $(p=0.39)$, or agreement that the content covered at Level 3 helped them with their degree studies $(p=0.13)$.

\section{Qualitative data}

No Level 3 students responded to the invitation to attend focus groups. Additional comments within the questionnaire were the only source of qualitative information available from the group. These showed that students felt a greater sense of belonging to the college than the university mostly due to the geographical location of the foundation year on a different campus; but some also perceived that the university did not make much of an effort to welcome them. Comments about the induction mostly related to confusion about some aspects of the foundation year; what subjects would be taken, where the year was held and how it related to the university. Confidence levels relating to Level 4 study were generally but not universally high, suggesting that some students need additional support with transition. Focus group data were limited to two focus groups, held with Level 4, 5 and 6 students $(n=6)$. Although limited, focus group themes aligned with the qualitative data collected from the questionnaires. Focus group participants did not feel a strong sense of belonging to the university and the geographical location of the foundation year in a sister college rather than at the university itself contributed to this. Focus group participants also felt that the provision of activities which would have allowed them to meet previous foundation students now studying at the university would have helped 
them feel that they belonged. This is a possible strategy that could be used to ensure that students attending accredited degrees at other institutions, or completing a university foundation year hosted at another institution feel included and part of their university. The majority agreed that what they studied in the foundation year was appropriate. Qualitative data were previously reported in depth (Goldring et al, 2018).

\section{Discussion}

Overall, the main findings of this project related to current Level 3 students since they were the largest group. The majority of these students were satisfied with the foundation year. This is impressive given the considerable heterogeneity among foundation degree students in this study. Such heterogeneity is in line with the widening participation focus now common in higher education (Crabtree \& Roberts, 2007), but presents challenges for both individuals and institutions (Gonsalves et al, 2011). Although in this study most participants had entered the foundation year via traditional $A$ levels, many were first in their families to attend higher education $(32 \%)$, mature $(39 \%)$ or BME students (54\%), similarly to other studies (Gill, 2019). The literature identifies these as groups for whom transition to higher education is likely to pose more challenges (Bathmaker \& Thomas, 2009; Clayton et al, 2009). There are several reasons why this might be the case. Mature students may have less of a sense of authentic belonging within higher education due to the difficulty of managing multiple commitments (Christie et al, 2005). BME students may feel alienated if they live at home while studying, and often studying in a social culture in which alcohol consumption is the norm (Stevenson, 2012; Singh, 2009). Those who are first in their families to attend university may lack the cultural capital to deal with higher educational issues (Vryonides, 2007). Student expectations of higher education will be shaped in part by their previous life experiences (Maunder et al, 2013; Busher et al, 2014). Within our study, $43 \%$ of participants had not entered university via the traditional A levels route. Thus in many potentially important respects they were a diverse group, which poses challenges in terms of support. The most important issues identified in this study included a sense of belonging at the university, differing support needs and lower levels of satisfaction with induction among Black students, which will be discussed in turn.

\section{Belonging}

It appears from this study that the university is failing to foster a sense of belonging among many foundation students, due in part to the geographical location of the first year in a neighbouring college. Housing foundation year studies in sister colleges is not unusual in higher education, but similar issues may arise in programmes housed across different campuses of the university, or courses accredited by universities but located in affiliated institutions. The issues identified are not unique to this institution or this instance of course provision. Our finding that students who felt part of the university, rather than solely the college, were also more likely to agree that the foundation year met their expectations demonstrates the importance of this first transition year. Approximately $10 \%$ of foundation year students leave after the foundation year, an important loss to the institution as well as the individuals concerned. Exploring possible reasons for this is important.

Where students feel more connected to the institution, staff and their peers, managing transitions is easier (Tett et al, 2017; Gibson et al, 2018), and an association between a sense of belonging and student retention has been shown (Hausmann et al, 2007; Hoffman et al, 2002). This study did not find a link between feeling part of the college and agreement that the foundation course met expectations. However, students who felt part of the university were significantly more likely to agree or strongly agree that the course met their expectations. This may reflect the fact that foundation students are registered to a university degree, although their first year is spent at the neighbouring college. It does highlight the importance of ensuring that foundation students feel welcome and integrated within the university, not just the college. This was not always the case, mostly because of the geographical location of the first year (Goldring et al, 2018). Those who 
did comment that they felt either at home at the university or at home both in the college and university, tended to be those who had engaged with extracurricular opportunities such as societies and clubs (Goldring et al, 2018). Whilst these are clearly helpful in managing transition, they should not be relied on. The most helpful engagement activities are those with an overt academic purpose hosted within the academic framework (Thomas, 2012), with social activities complementing but not replacing them (Tinto, 1993), since not all students will take part in social activities. Students most likely to struggle with transition (e.g. mature and/or BME students) may be least likely to avail of social activities for a variety of reasons including other commitments (Christie et al, 2005; O'Donnell \& Tobell, 2007) and an alcohol-centric student environment which may be at odds with their personal, religious or cultural identity (Singh, 2009; Stevenson, 2012). Integrating induction into the academic offer ensures that all students can benefit from it (Thomas, 2012), but how may this be achieved in practice? Building relationships with staff is key: it is an integral part of helping students develop a sense of belonging and identity within higher education (Zepke \& Leach, 2010; Briggs et al, 2012; Thomas, 2012; Cheng et al, 2015a; Tett et al, 2017; Breeze et al, 2018). Early contact with staff and small group work have been shown to aid transition (Brooman \& Darwent, 2014), as has fostering positive relationships with peers and staff (Tett et al, 2017). This requires time, commitment and institutional support, and needs to occur on an ongoing basis (Thomas, 2012).

\section{Support}

In this study, support needs valued by students altered by year of study, which may reflect the ongoing nature of transition (Maunder et al, 2013; Tett et al, 2017). Different skills may be required at different transition points into and within higher education (Cheng et al, 2015b). In this study, personal support was identified by previous Level 3 students as important, and its importance increased throughout their university life (Table 2). The role of academics and teaching in enhancing student engagement is well recognised in the literature (Kuh et al, 2006; Zepke \& Leach, 2010), and personal relationships with academics are an important facet of how students perceive quality in higher education (Dicker et al, 2018). The finding in the current study that personal support from individual academics and personal tutors as well as via academic office hours is highly valued by students suggests that attention to induction and successful transition is important not just for student retention but may also influence their view of whether or not they consider their higher education experience to be of high quality. Similarly to other work (Zepke \& Leach, 2010; Thomas, 2012), this study also identified the importance of other support services (e.g. the library). Others have shown that students recognise the need to become independent learners but may have concerns about how to achieve this (Leese, 2010), or lack support in doing so (Pennington et al, 2018). Since many students on foundation degrees are non-traditional, they may be more accustomed to vocational style assessments, so their skills, experience and expectations are likely to be very different from traditional A level students (Gill, 2017). Skills acquisition and academic support in developing these skills as well as peer support have been shown to help students develop confidence in their own abilities as learners (James et al, 2015), and are identified as key transition skills. Mature students value support to help them develop as independent learners, collaborative working with other students and respect from their tutors (Busher et al, 2015). Fostering a sense of belonging within the institution, aligned with academic and social engagement is key to helping students engage in higher education (Thomas, 2012). Academic staff can help to address the need for support and to foster belonging in this group, and involving university staff from the accrediting institution in delivering teaching students on the foundation year may help (Gill, 2019).

A mixture of emotions related to foundation year was apparent amongst Level 3 students, reflecting the complex nature of transition to higher education (Cheng et al, 2015a). Some of these were specific to mature students, who felt out of place in the college (where the student body is largely young in age). Early 
contact with mature students has been shown to help reduce their fears about returning to study particularly at HE level (Burton et al, 2011). Student expectations of university in the UK include directed and non-directed time, support and relationships with staff and peers (Money et al, 2017). A mismatch of expectations is more likely to lead to lack of integration with a possible impact upon retention and progression (Laing et al, 2005; Bates \& Kaye, 2014). Those with more accurate expectations tend to have a better transition (Denovan \& Macaskill, 2013; Maunder et al, 2013; Cole, 2017). However a strong perception of a lack of clarity about the nuts and bolts of the foundation year was also expressed in this study (e.g. modules to be undertaken, location of the teaching), which is likely to have contributed to student dissatisfaction. Although this information was made available to applicants, the finding suggests that information given was not necessarily acknowledged or remembered. Dissatisfaction with the clarity of information about the foundation year was most acute in Black students and although numbers were low, this needs further exploration. How, as well as what and when, information is given, is likely to impact upon whether it is remembered and accessed. Our induction to higher education, similar to others (Laing et al, 2005), is very information-focused, and decisions about what information should be given, in what format and when in order to maximise usefulness to students is worth considering. Possible interventions preinduction include information provision which will help students to make informed decisions (Thomas, 2011). This may help manage expectations and lessen the chance of a mismatch between what is expected and what actually occurs, which can lead to student withdrawal (Bowles et al, 2011). Clearly a substantial number of Level 3 respondents did not understand why they were required to take specific modules, and this translated into a negative view about the entire course. Attention to induction as a whole matters; university induction is often presented as an initial one-off week at the beginning of the first term (which was the case here). Transition is a dynamic process which will continue throughout students' education, but is likely to be most acute in the early days of university
(Christie et al, 2016). It should be recognised as a process which is part of a wider transition to higher education and continues over the whole of the first year and beyond (Tett et al, 2017; Bowles et al, 2014; Holdsworth, 2006; Reay, 2002), and integrated within the academic framework to benefit all students. Our findings suggest that where foundation courses are housed outside of the university, care and attention to ensuring that foundation students are integrated into the university is needed. Surprisingly, whether or not students had intended to take the foundation year had no impact on their satisfaction with the programme, induction, or support given.

This study is not without limitations. Although over a third of eligible students in foundation year participated, numbers in other year groups (especially levels 4 and 5) were low. This is likely to be due to the method of data collection used, chosen for pragmatic reasons. A fifth of eligible final year students participated, perhaps because with the benefit of hindsight they could understand the issues relating to transition in their experience. Focus group participation was also low, although this was somewhat mitigated by qualitative comments included within the questionnaire.

\section{Conclusion}

Despite considerable heterogeneity within the group, most current foundation students in this study were satisfied with the foundation year. Black students were less satisfied with the induction, accuracy of course description and were less likely to feel that the foundation year was meeting their expectations. This requires further exploration. For all students, it is essential that there is clarity about what is involved in the programme, especially if it is delivered off the university site.

A sense of belonging to the university appears to be important in whether or not students feel the course has met their expectations, and in this study, many students did not feel part of the university. Fostering a sense of belonging throughout the transition to higher education by facilitating the development of relationships with each other and academic staff is recommended. Ideally this should be integrated within the academic framework to increase accessibility. A clear role for 
academic staff in fostering a sense of belonging and helping to equip students with academic skills was seen. This was important at all stages of university life, but increased in importance as students progressed.

\section{References}

Bates, E.A. \& Kaye, L.K. (2014). 'l'd be expecting caviar in lectures': The impact of the new fee regime on undergraduate students' expectations of higher Education. Higher Education 67(5): 655-673. DOI: 10.1007/510734-013-9671-3.

Bathmaker, M.A., \& Thomas, W. (2009) Positioning themselves: an exploration of the nature and meaning of transitions in the context of dual sector FE/HE institutions in England. Journal of Further and Higher Education 33(2): 119-130. DOI: $10.1080 / 03098770902856652$

Bowles, A., Fisher, R., McPhail, R., Rosenstreich, D. \& Dobson, A. (2014). Staying the distance: students' perceptions of enablers of transition to higher education. Higher Education Research and Development 33(2): 212-225.

DOI: $10.1080 / 07294360.2013 .832157$.

Bowles, A., Dobson, A., Fisher, R., \& McPhail, R. (2011). An exploratory investigation into first year student transition to university. Research and Development in Higher Education 34: 61-71. ISBN $090855785 \mathrm{X}$.

Breeze, M., Johnson, K., \& Uytman, C. (2018). What (and who) works in widening participation? Supporting direct entrant student transitions to higher education. Teaching in Higher Education, DOI: 10.1080/13562517.2018.1536042.

Briggs, A.R.J., Clark, J. \& Hall, I. (2012). Building bridges: understanding student transition to university. Quality in Higher Education 18(1): 3-21. DOI: $10.1080 / 13538322.2011 .614468$

Brooman, S., \& Darwent, S. (2014). Measuring the beginning: a quantitative study of the transition to higher education. Studies in Higher Education 39(9): 1523-1541. DOI: $10.1080 / 03075079.2013 .801428$

Burton, K., Golding Lloyd, M. \& Griffin, C. (2011). Barriers to learning for mature students studying $H E$ at an FE college. Journal of Further and Higher Education 35(1): 25-36. DOI: 10.1080/0309877X.2010.540231.

Busher, H., James, N., Piela, A. \& Palmer, AM. (2014). Transforming marginalised adult learners' views of themselves: Access to Higher Education courses in England. British Journal of Sociology of Education 35: 800817. DOI: $10.1080 / 01425692.2014 .919842$

Busher, H., James, N. \& Piela, A. (2015). On reflection: mature students' view of teaching and learning on Access to Higher Education Courses. International Studies in Sociology of Education 25(2): 296-313. DOI: $10.1080 / 09620214.2015 .1083405$

Cheng, M., Pringle Barnes, G., Edwards, C., \& Valyrakis, M. (2015a). Transition Skills and Strategies. Transition models and how students experience change. Glasgow: QAA Scotland. Available from: https://www.academia.edu/17659922/student transition transition models

Cheng, M., Pringle Barnes, G., Edwards, C., Valyrakis, M. \& Corduneanu, R .(2015b). Transition Skills and Strategies. Key Transition Skills. Glasgow: QAA Scotland. Available from: https://www.researchgate.net/publication/2834 59965 transition-skills-and-strategies---keytransition-skills-at-the-different-transitionpoints

Christie, H., Munro, M. \& Wager, F. (2005). Day students in higher education: Widening access students and successful transitions to university life. International Studies in Sociology of Education 15(1): 3-29. DOI: $10.1080 / 09620210500200129$

Christie, H., Tett, L., Cree, V.E. \& McCune, V. (2016). 'It all just clicked': a longitudinal perspective on transitions within university. Studies in Higher Education 41(3): 478-490. DOI: $10.1080 / 03075079.2014 .942271$ 
Clayton, J., Crozier, G. \& Reay, D. (2009). Home and away: risk, familiarity and the multiple geographies of the higher education experience. International Studies in Sociology of Education 19(3-4): 157-174. DOI: $10.1080 / 09620210903424469$

Cole, J.S. (2017). Concluding comments about student transition to higher education. Higher Education 73(3): 539-551. DOI: 10.1007/s10734-016-0091-z

Crabtree, H. \& Roberts, C. (2007). Understanding the Problems of Transition into higher education. Available online at: http://www.ece.salford.ac.uk/proceedings/pap ers/35 07.pdf

Crossan, B., Field, J., Gallacher, J. \& Merrill, B. (2003). Understanding participation in learning for non-traditional adult learners: Learning careers and the construction of learning identities. British Journal of Sociology of Education 24(1): 55-67. DOI: $10.1080 / 01425690301907$

Denovan, A. \& Macaskill, A. (2013). An interpretative phenomenological analysis of stress and coping in first year undergraduates. British Educational Research 39(6): 1002-1024. DOI: 10.1002/berj.3019

Dicker, R., Garcia, M., Kelly, A. \& Mulrooney, $\mathrm{H}$. (2018). What does 'quality' in higher education mean? Perceptions of staff, students and employers. Studies in Higher Education 44(8): 1425-1441. DOI: 10.1080/03075079.2018.1445987

Frame, P., Harwood, T., Hoult, L., Jenkins, M., Lynch, K. \& Volpe, G. (2006). Transitions into Higher Education: processes, outcomes and collaborations. In: Proceedings of the Association of Tertiary Learning Advisors Aotearoa, Supporting Learning in the 21st century. Dunedin, New Zealand. Available from:

https://www.academia.edu/28769353/Transiti ons into Higher Education processes outco $\underline{\text { mes and collaborations }}$

Gale, T. \& Parker, S. (2014). Navigating change: a typology of student transition in higher education. Studies in Higher Education
39(5):

734-753.

DOI:

10.1080/03075079.2012.721351.

Gibson, S., Grace, A., O'Sullivan, C. \& Pritchard, C. (2018). Exploring transitions into the undergraduate university world using a student-centred framework. Teaching in Higher Education 24(7): 819-833. DOI: 10.1080/13562517.2018.1511538

Gill, A. (2017). The transitional experiences of sport and exercise students from further to higher education. Innovative Practice in Higher Education 3(1): 22- 47. ISSN 20443315.

Gill, A. (2019). Student Transition into Higher Education: Exploring BTEC Sport and Exercise Students Forthcoming Transition to Higher Education Taught within a Further Education Setting. Innovative Practice in Higher Education 3(3): 90-112. ISSN: 20443315

Goldring, T., Harper, E., Jassal, R., Joseph, L., Kelly, A., Mulrooney, H., Piper, I. \& Walker, H. (2018). Experiences and expectations of transition to higher education: a qualitative approach. New Directions in the Teaching of Physical Sciences 13(1). DOI: 10.29311/ndtps.v0i13.2849

Gonsalves, A., Seiler, G. \& Salter, D.E. (2011). Rethinking resources and hybridity. Cultural Studies of Science Education 6: 389399. DOI: 10.1007/s11422-010-9275-5

Hausmann, L.R.M., Schofield, J. \& Woods, R. (2007). Sense of belonging as a predictor of intentions to persist among African American and White first-year college students. Research in Higher Education 48(7): 803-839. DOI: $10.1007 / \mathrm{s} 11162-007-9052-9$

Hoffman, M., Richmond, P.D.J., Morrow, J. \& Salomone, P.D.K. (2002). Investigating 'sense of belonging' in first-year college students. Journal of College Student Retention: Research, Theory and Practice 4(3): 227-256. DOI: 10.2190\%2FDRYC-CXQ9-JQ8V-HT4V

Holdsworth, C. (2006). 'Don't you think you're missing out, living at home?' Student experiences and residential transitions. 
Sociological Review 54(3): 495-519. DOI: 10.1111/j.1467-954X.2006.00627.x

Hultberg, J., Plos,K., Hendry, G.D. \& Kjellgren, K.I. (2008). Scaffolding students' transition to higher education: Parallel introductory courses for students and teachers. Journal of Further and Higher Education 32(1): 47-57. DOI: $10.1080 / 03098770701781440$

Jackson, C. (2010). Transitions into Higher Education: Gendered implications for academic self-concept. Oxford Review of Education 29(3): 331-346. DOI: $10.1080 / 03054980307448$

James, N., Busher, H. \& Suttill, B. (2015). Using habitus and field to explore Access to Higher Education students' learning identities. Studies in the Education of Adults 47(1): 4-20. DOI: 10.1080/02660830.2015.11661671

Jindal-Snape, D. (2010) Educational Transitions: Moving Stories from Around the World. New York: Routledge. ISBN: $9780415647434 \quad 0415647436$ 97804158059190415805910

Kuh, G., Kinsey, J., Buckley, J., Bridges, B.K. \& Hayek, J.C. (2006). What matters to student success: A review of the literature. Report commissioned for the National Symposium on Postsecondary Student Success: Spearheading a Dialog on Student Success. Available from: https://nces.ed.gov/npec/pdf/Kuh Team Rep ort.pdf

Laing, C., Robinson, A. \& Johnston, V. (2005). Managing the transition into higher education. An online Spiral Induction Programme. Active Learning in Higher Education 6(3): 243-255. DOI: 10.1177\%2F1469787405059575

Leese, M. (2010). Bridging the gap: supporting student transitions into higher education. Journal of Further and Higher Education 34(2): 239-251. DOI: $10.1080 / 03098771003695494$

Maunder, R.E., Cunliffe, M., Galvin, J., Mjali, S. \& Rogers, J. (2013). Listening to student voices: student researchers exploring undergraduate experiences of university transition. Higher Education 66: 139-152. DOI: 10.1007/s10734-012-9595-3

Money, J., Nixon, S., Tracy, F., Hennessy, C., Ball, E. \& Dinning, T. (2017). Undergraduate student expectations of university in the United Kingdom: What really matters to them? Cogent Education 4: 1301855. DOI:10.1080/2331186X.2017.1301855

O'Donnell, V.L. \& Tobbell, J. (2007). The transition of adult students to Higher Education: legitimate peripheral participation in a community of practice? Adult Education Quarterly 57(4): 312-328. DOI: $10.1177 \% 2 F 0741713607302686$

O'Donnell, V.L., Kean, M. \& Stevens, G. (2016). Student transition in higher education. Higher Education Academy. Available from: https://www.heacademy.ac.uk/system/files/do wnloads/student transition in higher educati on.pdf

O'Shea, S.E. (2015). Filling up silences - first in family students, capital and university talk in the home. International Journal of Lifelong Education 34(2): 1-17. DOI: $10.1080 / 02601370.2014 .980342$

O'Shea, S. (2016). First-in-family learners and higher education: Negotiating the 'silences' of university transition and participation. HERDSA Review of Higher Education 3: 5-23. Available from: https://www.herdsa.org.au/herdsa-reviewhigher-education-vol-3/5-23

Pennington, C.R., Bates, E.A., Kaye, L.K. \& Bolam, L.T. (2018). Transitioning in higher education: an exploration of psychological and contextual factors affecting student satisfaction. Journal of Further and Higher Education 42(5): 596-607. DOI: 10.1080/0309877X.2017.1302563

Price, M., Handley, K. \& Millar, J. (2011). Feedback: Focusing attention on Engagement. Studies in Higher Education 36(8): 879-896. DOI: $10.1080 / 03075079.2010 .483513$ 
Ramsay A., Raven, J. \& Hall, M. (2005). Changing the learning environment to promote deep learning approaches in firstyear accounting students. Accounting Education 13(4): 489-505. DOI: $10.1080 / 0963928042000306837$

Reay, D. (2008). Class, Authenticity and the Transition to Higher Education for Mature Students. Sociological Review 50 (3): 398418. DOI: 10.1111/1467-954X.00389

Reay, D., Crozier, G. \& Clayton, J. (2010). 'Fitting in' or 'standing out': working -class students in UK higher education. British Educational Research Journal 36(1): 107-124. DOI: 10.1080/01411920902878925

Singh, G. (2009). Black and Minority Ethnic (BME) students' participation in higher education: improving retention and success. UK: Higher Education Academy. Available from:

https://www.advance-

he.ac.uk/knowledge-hub/black-and-minority-

ethnic-bme-students-participation-higher-

education-improving

Southall, J., Wason, H. \& Avery, A. (2016). Non-traditional, commuter students and their transition to Higher Education - a synthesis of recent literature to enhance understanding of their needs. Student Engagement and Experience Journal 5 (1): 1-15. DOI: 10.7190/seej.v4i1.128

Stevenson, J. (2012). Black Minority Ethnic Student Degree Retention and Attainment. UK: Higher Education Academy. Available from:

https://s3.eu-west2.amazonaws.com/assets.creode.advancehedocumentmanager/documents/hea/private/bme summit final report 1568036653.pdf

Strayhorn, T.L. (2012). College students' sense of belonging: $A$ key to educational success. New York: Routledge. DOI: 10.4324/9780203118924

Tett, L., Cree, V.E. \& Christie, H. (2017). From further to higher education: transition as an on-going process. Higher Education 73: 389406. DOI: $10.1007 / \mathrm{s} 10734-016-0101-1$
Thomas, L. (2011). Do pre-entry interventions such as 'AimHigher' impact on student retention and success? A review of the literature. Higher Education Quarterly 65(3): 230-250. DOI: 10.1111/j.14682273.2010.00481.x

Thomas, L. (2012). Building student engagement and belonging in Higher Education at a time of change. Final Report from the What Works? Student Retention and Success programme. London: HEA/Paul Hamlyn Foundation. Available from: https://www.advance-he.ac.uk/knowledgehub/building-student-engagement-andbelonging-higher-education-time-change-finalreport

Tinto, V. (1993). Leaving college: Rethinking the causes and cures of student attrition. 2nd edition. Chicago: University of Chicago Press.

Tobolowsky, B.F. (2008). Sophomores in transition: The forgotten year. New Directions for Higher Education 144: 59-67. DOI: $10.1002 /$ he.326

Vryonides, M. (2007). Social and cultural capital in educational research: Issues of operationalism and measurement. British Educational Research Journal 33(6): 867-885. DOI: $10.1080 / 01411920701657009$.

Wainwright, E. \& Watts, M. (2019). Social mobility in the slipstream: first-generation students' narratives of university participation and family. Educational Review. DOI: 10.1080/00131911.2019.1566209

Wainwright, E. \& Marandet, E. (2010). Parents in higher education: impacts of university learning on the self and the family. Educational Review 62: 449-465. DOI: $10.1080 / 00131911.2010 .48764$

Waite, S. (2013). 'Knowing your place in the world': how place and culture support and obstruct educational aims. Cambridge Journal of Education 43: 413-433. DOI: 10.1080/0305764X.2013.792787

Zepke, N., \& Leach, L. (2010). Improving student engagement: Ten proposals for action. Active Learning in Higher Education 
Transition to higher education; prospective and retrospective student experiences

11(3): 167-77. DOI:

$10.1177 \% 2 F 1469787410379680$ 